\title{
Monitoring technical state of pipelines in difficult conditions
}

\author{
A.N. Dmitrievsky ${ }^{1}$, N.A. Eremin ${ }^{1 *}$, L.A. Husnutdinov ${ }^{2 *}$ \\ 1 - Oil and Gas Research Institute, Russian Academy of Sciences, Moscow; \\ 2 - Transkor-K Scientific and Technical Center, Moscow \\ E-mail:*ermn@mail.ru, **inya82@mail.ru
}

Abstract. The paper deals with the innovative methods for monitoring the technical state of pipelines in difficult conditions. Within the framework of the methodology of Risk Based Inspection, the approach is analyzed using the innovative magnetic tomography method, which offers the inclusion of the registration of real mechanical stresses in the system for assessing the reliability of pipelines by the criterion of transition to the limit state based on the registration of the degree of stress concentration or excess of local loads.

Keywords: oil pipeline, gas pipeline, magnetic tomography method, stress-corrosion processes, Villary effect, corrosion, stress corrosion cracking, metal embrittlement, in-line inspection, pipeline condition monitoring, stress-strain state, ferromagnetic material.

Citation: Dmitrievsky A.N., Eremin N.A., Husnutdinov L.A. Monitoring technical state of pipelines in difficult conditions // Actual Problems of Oil and Gas. 2019. Iss. 3(26). https://doi.org/ 10.29222/ipng.2078-5712.2019-26.art12

Pipeline is an engineering system of a lengthy network of seamless or welded-on pipes designed for the delivery of commercial gas, oil or oil products from fields to consumers in the domestic or global commodity market (refinery, gas processing plant, liquefied natural gas plant, marine terminal and others).

The length of trunk pipelines in Russia is more than 250 thousand $\mathrm{km}$, and gas pipelines and gas pipelines-branches of PJSC Gazprom in Russia is 172.6 thousand km as of 01.01.2009. According to the international consulting company KPMG, PJSC Transneft is the leader among oil pipeline companies in terms of the volume of oil transportation -478 and oil products -33 million tons and the length of oil pipelines -51.5 and oil product pipelines -16.9 thousand $\mathrm{km}$ as of 01.01.2018. Total length of field pipelines in Russia exceeds 0.35 million $\mathrm{km}$.

Internal and external corrosion are the main causes of pipeline accidents. Internal corrosion was the cause of about $15 \%$ of gas pipeline accidents over the past 30 years, according to Pipeline and Hazardous Materials Safety Administration (PHMSA) database.

Table 1 presents the causes of accidents on gas and oil pipelines according to the data of the Federal Service for the Supervision of Environment, Technology and Nuclear Management of the Russian Federation in 2006-2016. 
Table 1

Causes of accidents at gas pipelines and oil pipelines. Source: annual reports on the activities of the Federal Service for Ecological, Technological and Nuclear Supervision for 2006-2016

\begin{tabular}{|c|c|}
\hline $\begin{array}{c}\text { Causes of accidents at gas pipelines for 2006- } \\
2016 \text { (total of } 146 \text { accidents) }\end{array}$ & $\begin{array}{c}\text { Causes of accidents at oil pipelines for 2006-2016 } \\
\text { (total } 53 \text { accidents) }\end{array}$ \\
\hline Pipe metal corrosion $-50.7 \%$ & Unauthorized taps $-55.8 \%$ \\
\hline $\begin{array}{l}\text { Marriage of construction / manufacturing - } \\
26.7 \%\end{array}$ & $\begin{array}{l}\text { Marriage of construction / manufacturing - } \\
23.1 \%\end{array}$ \\
\hline Mechanical impact - $14.4 \%$ & Errors in operation $-5.8 \%$ \\
\hline Errors in operation $-4.1 \%$ & Corrosion of metal pipes $-5.8 \%$ \\
\hline Constructive defects $-2.7 \%$ & Constructive defects $-5.8 \%$ \\
\hline Natural disasters $-0.7 \%$ & Mechanical impact $-3.8 \%$ \\
\hline Equipment wear $-0.7 \%$ & - \\
\hline
\end{tabular}

The non-contact diagnostic method allows the detection of internal and external corrosion at an early stage of its development. This diagnostic method ensures structural integrity and reliable operation of pipelines both at sea and on land.

To date, many problems have been solved in the system of monitoring the technical condition of pipelines. The challenge remains to ensure the reliability of pipelines in difficult operating conditions. Modern methods of monitoring include the acoustic method of nondestructive testing; distributed control systems with fiber optic cable along the axis of objects; as well as direct measurements during periodic inspections of the metal surface of the pipeline by crawlers.

The essence of the acoustic method of non-destructive testing is to register with the help of a microphone the characteristic noise of a flowing fluid through a pipeline. The flow of a liquid product at a constant cross section of the pipeline has low turbulence, without vortices and discontinuity of uniformity, while there is practically no sound emission. With the help of a microphone attached to the outside of the pipe wall, you can register the characteristic noise of a flowing fluid. This noise propagates through the liquid and metal of the pipe to both sides of the source and can be detected by sensitive equipment at a distance of up to $100 \mathrm{~m}$, depending on the pressure in the pipeline and ground conditions. The location of the violation of the full- pass section of the pipeline is detected by reducing the intensity of the sound when moving away from the source with the help of special equipment for recording a phonogram with a record on the computer. The main advantages of the method include good sensitivity to identify areas for reducing the flow area of the pipeline, and the main disadvantages are the complexity of the application (providing access to the metal surface of the underground object) and the need to 
ensure the acoustic silence within a radius of $500 \mathrm{~m}$ from the point of operation of the system [1].

Monitoring systems based on fiber-optic cables allow to control soil movements, formation of deflections and bends of the pipeline, attempts to carry out unauthorized tie-ins and product leakage due to depressurization. The use of fiber-optic systems is limited by the need to install them directly on the pipeline during construction or planned re-insulation. Minor damage of a fiber-optic monitoring system during the installation process will lead to its complete or partial failure $[2,3]$.

Traditional monitoring of the state of the pipeline is carried out by measuring the parameters of electrochemical protection (ECP), for example, the corrosion wear of the wall. Electrometry is an insufficiently reliable tool for assessing the state of the metal pipeline, since corrosion defects of the metal are not sufficiently monitored, including the dynamics of the development of defects of other origin. Diagnostics of the technical condition on the basis of periodic non-destructive testing of the metal is carried out by fixing the state of the pipeline metal at a certain moment with subsequent calculations of predicted indicators in the future based on different models and rates of metal degradation (corrosion, cracking, plastic deformation during warping, buckling, embrittlement etc.) [4-6].

Data on the state of the metal throughout the pipelines up to the last decade could be obtained only if it was examined by the in-line inspection. Speaking of such a monitoring system, it is impossible not to take into account its significant limitations due to the lack of initial information about local loads in real operating conditions and the nonlinearity of the processes of metal degradation.

The above disadvantages are devoid of a diagnostic method using a non-contact magnetic tomography method (MTM) [7]. The method is designed to detect localized abnormal stresses in the pipe wall by mapping changes in the magnetic field around pipelines.

If a downward (or upward) force is applied to the upper (or lower part) of the pipe, then its magnetic response will be immediately detected by a magnetometer. This phenomenon is called the magnetization of the stress state of a ferromagnetic material. In the manufacturing process of ferromagnetic pipes, the molten material freezes outside its Curie point. In this case, the ferromagnetic material actually becomes a bar magnet with a north and south pole. Magnetic domains in it are linearly oriented along their length. 
Such processes as corrosion, cracking and technological damage to pipes lead to the appearance of sections of pipelines with high stress state. The magnetic field strength decreases with increasing distance from the pipe. High diagnostic accuracy is achieved when the distance from the magnetometers to the center line of the pipe does not exceed 15 times the diameter of the pipe.

Table 2 shows the technical specifications of the digital three-component magnetometer.

Specifications

Table 2

\begin{tabular}{|l|l|}
\hline Component measuring range & $\pm 70,000 \mathrm{nT}$ \\
\hline Sensitivity & $2 \mathrm{nT}$ \\
\hline Measurement error & not more than $0.5 \%$ \\
\hline Zero offset error & not more than $\pm 20 \mathrm{nT}$ \\
\hline The accuracy of the orthogonality of the axes & $\begin{array}{l}\text { not more than } 15 \text { angles } \\
\text { minutes }\end{array}$ \\
\hline Supply voltage & $+5 \mathrm{~V}$ \\
\hline Power Consumption & $0.2 \mathrm{~W}$ \\
\hline Weight & $0.065 \mathrm{~kg}$ \\
\hline Operating temperature range & from $-35^{\circ} \mathrm{C}$ to $+65^{\circ} \mathrm{C}$ \\
\hline
\end{tabular}

The essence of the technology is an integrated approach to monitoring the technical condition of the pipeline by control of the stress-strain state of the metal throughout the pipeline without changing its operating modes. Data collection about the pipeline and its diagnostics is carried out in normal operation. To calculate the deviation of the pipeline from the design position and identify sections of the pipeline with increased mechanical stresses, a mathematical model is used. Identified anomalies along the pipeline route are marked on the ground, and external sensors are installed on high-risk areas for real-time monitoring.

The MTM monitoring system is at a predetermined distance above pipeline with an equipment of fixing and recording the parameters of the magnetic field in time. The system can transmit the data of the primary survey, because it can be sent to the operator's console or to a memory card, while the data is collected in accordance with the approved regulations (the frequency of the survey) depending on the actual speed of the metal degradation process. 
Repeated complex diagnostics of the pipeline is carried out after 3-5 years to amend the mathematical model and identify areas of new deviations from the norms to install additional monitoring points. Such a two-stage monitoring system based on continuous monitoring of the magnetic properties of the metal allows the dispatcher to monitor the condition of the pipeline metal in real time and make operational decisions on the maintenance adjustment taking into account the identified risk. MTM is based on the well-known Villari effect (inverse magnetostriction) - the relationship discovered more than 200 years ago between the change in stresses (deformations) of ferromagnetic metals and the magnetic response due to a change in the orientation of the magnetic spins of the domains $[8,9]$.

The conditional probability of the formation of corrosion defects in pipelines is given in table 3.

Table 3

\section{Conditional probability of corrosion defects in pipelines}

\begin{tabular}{|c|c|c|c|}
\hline efect length, $\mathrm{mm}$ & Pinhole & Puncture & Rapture \\
\hline $203-254$ & 0.68 & 0.26 & 0.06 \\
\hline $254-508$ & 0.65 & 0.22 & 0.13 \\
\hline$>508$ & 0.67 & 0.21 & 0.12 \\
\hline
\end{tabular}

Source: Office of Pipeline Safety under the Pipeline and Hazardous Materials Safety Administration OPS PHMSA, 2010.

The concept of ensuring the safety of pipeline transport facilities was created on the basis of quantitative indicators of the reliability of inspection. In particular, applying the modern methodological approach of risk-based inspection and in line with international standards of the Forum of Pipeline Operators (POF), such evaluation parameters as the probability of detecting anomalies at $100 \%$ metal control volume (POD), the probability of interpreting the degree of danger of anomalies were proposed by rank depending on the degree of concentration of mechanical stresses (POIn) and the reliability of the technology as a whole. In the report, a pipeline operator will receive the data not only on the effective stresses in each identified anomaly, but also the period of the trouble-free operation $-\mathrm{T}_{\text {safe }}$, the safe working pressure $-\mathrm{P}_{\text {safe }}$ and the estimated repair factor - ERF.

The distribution of stress values along the pipeline axis depends on many factors or local loads due to operating conditions, external influences, as well as various types of defects (stress concentrators). For example, corrosion, which reduces the thickness of the pipe wall, increases local stresses in the area of loss of the bearing capacity. This causes an anomaly in the magnetic 
field of the pipeline as the magnetic spins in the stress concentrator region tend to change their spatial orientation due to deformations in the metal crystal lattice.

In October 2017, the world's first project to diagnose the gas pipeline of OJSC Alrosa Gas at water crossings across the Vilyui and the Bolshaya Butobiya rivers, with a total length of about $2 \mathrm{~km}$ using a multicopter, was successfully completed. The innovative technology of contactless diagnostics of pipelines based on multikopter was created by the scientific centers of the Oil and Gas Research Institute of the Russian Academy of Sciences: magnetic tomography, the supervisor of the Ph.D. S.S. Kamaeva, and monitoring and geophysical studies using the UAV, the supervisor, Ph.D. A.D. Chernikov (see Figure). As a result of the experimental work on the inspection of water crossings of the gas pipeline of the company - OJSC Alrosa Gas - by the method of magnetic tomography using unmanned aerial vehicles, the main elements of the robotic technology of inspection of the state of the pipelines were worked out $[10,11]$.

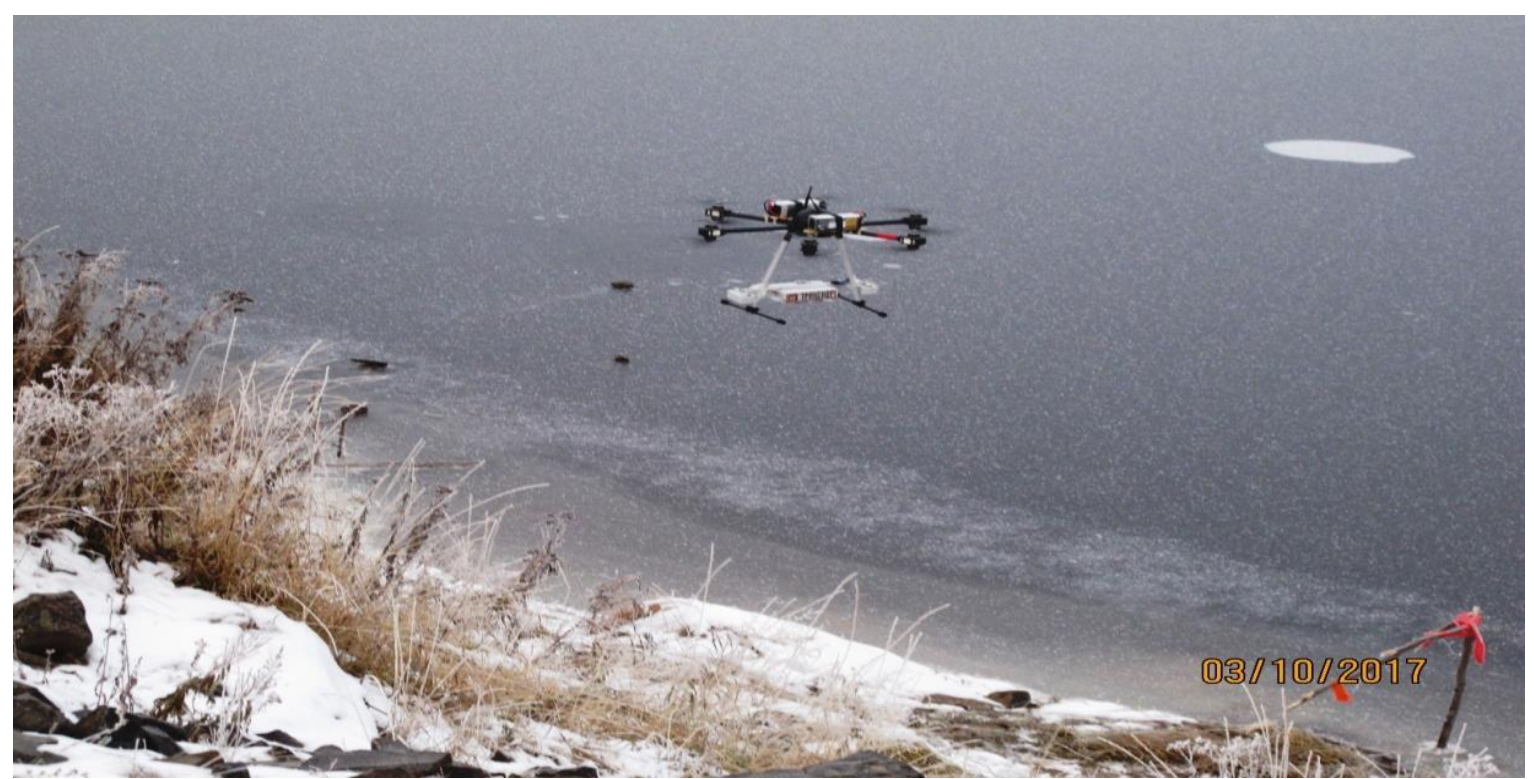

Figure. The innovative technology of contactless diagnostics of pipelines based on multikopter

\section{Conclusion}

Dependencies of the magnetic field characteristics of the pipeline on stresses of different nature were established during numerous tests both in Russia and abroad (Malaysia, India, USA, Norway, Italy and others). In particular, a non-contact magnetic tomography method was tested at the Petronas field test site as a technology for assessing local stresses in areas with known artificial defects under stepped loading of the pipeline. The evaluation was carried out by comparing the MTM readings on the values of local stresses with the data of strain gauges 
installed in the defect zone, as well as by the numerical simulation. Calculations were carried out according to generally accepted methods (ASME, API Part 1, 2; DNV, FEM.). High correlation coefficients of the final data with the data of the above contactless monitoring methods were recorded. At the same time, MTS results were more conservative compared to other methods, but the differences did not exceed $10 \%$.

Domestic technology of contactless diagnostics of pipelines using the method of magnetic tomography (MTM) has proved its high efficiency. The system was implemented in 34 countries of the world on both gas and oil pipelines. Since 2002, pipelines with a total length of over $20.000 \mathrm{~km}$ have been diagnosed, of which the length of offshore pipelines with a water depth of up to $1.500 \mathrm{~m}$ was $1.800 \mathrm{~km}$. The export potential of the system of contactless diagnostics of pipelines using the method of magnetic tomography (MTM) is very high.

Статья написана в рамках выполнения государственного задания (тема «Фундаментальный базис инноващионных технологий нефтяной $u$ газовой промышленности (фундаментальные, поисковые и прикладные исследования)», № ААААA19-119013190038-2).

\section{References}

1. Belov A.A., Ivanov Yu.D., Shestakov A.A., Tsareva S.G., Shishkov E.V. Recommendations on the choice of the method of monitoring the technical condition of pipelines // Actual problems of Humanities and natural Sciences. 2015. № 10-1. P. 1-5.

2. ICE-CUBE. http://cae-cube.ru/ (Accessed on 11.02.2018). (In Russ).

3. Svelto C., Pniov A., Zhirnov A., Nesterov E., Stepanov K., Karassik V., Galzerano G., Laporta $P$. Online monitoring of gas \& oil pipeline by distributed optical fiber sensors // Offshore Mediterranean Conference and Exhibition, 27-29 March 2019: Proceedings. Ravenna, Italy, 2019. Paper OMC-2019-0830. 9 p.

4. Stubelj I.R., Ruschmann H., Wold K., Gomnaes J.O. Pipeline predictive analitics trough on-line remote corrosion monitoring // NACE Conference\&Expo CORROSION 2019, 24-28 March 2019: Proceedings. Nashville, Tennessee, USA, 2019. Paper NACE 2019-12899. $14 \mathrm{p}$.

5. Wright R.F., Egbu J., Buric M., Ziomek-Moroz M., Ohodnicki P.R., Lu P. Electrolessly coated optical fibers for distributed corrosion // NACE Conference\&Expo CORROSION 2019, 24-28 March 2019: Proceedings. Nashville, Tennessee, USA, 2019. Paper NACE 2019-13499. 12 p. 
6. Guan S., Ayello F., Sridhar N., Han X., Feng Q., Yang Y. Application of probabilistic model in pipeline direct assessment // NACE Conference\&Expo CORROSION 2019, 24-28 March 2019: Proceedings. Nashville, Tennessee, USA, 2019. Paper NACE 2019-12718. 13 p.

7. RD 102-008-2002 manual for diagnosis of technical state of pipelines noncontact method. Moscow: Publishing house of JSC VNIIST, the Ministry of Energy, 2003. 52 p.

8. Jarram P. Developments in remote magnetic monitoring of carbon steel pipelines to locate and measure abnormal stress // NACE Conference\&Expo CORROSION 2019, 24-28 March 2019: Proceedings. Nashville, Tennessee, USA, 2019. Paper NACE 2019-12995. 21 p.

9. Dmitrievsky A.N., Kamaeva S.S., Eremin N.A., Chernikov A.D. Contactless diagnostics of oil and gas pipelines: status and prospects of development // Actual Problems of Oil and Gas. 2018. Iss. 1(20). https://doi.org/10.29222/ipng.2078-5712.2018-20.art11 (In Russ.).

10. Marathe S. Leveraging Drone Based Imaging Technology for Pipeline and RoU Monitoring Survey // SPE Symposium: Asia Pacific Health, Safety, Security, Environment and Social Responsibility, 23-24 April 2019: Proceedings. Kuala Lumpur, Malaysia, 2019. Paper SPE-195427-MS. 18 p. https://doi.org/10.2118/195427-MS.

11. Eremin N.A., Husnutdinov L.A. Monitoring issues of stress - corrosion processes of internal industrial pipelines in complex conditions. // Neftânaâ Provincia. 2018. No. 4(16). P. 196-211. https://doi.org/10.25689/NP.2018.4.196-211 (In Russ.). 


\title{
Мониторинг состояния трубопроводов в сложных условиях
}

\author{
А.Н. Дмитриевский ${ }^{1}$, Н.А. Еремин ${ }^{1 *}$, Л.А. Хуснутдинов ${ }^{2^{* *}}$ \\ 1 - Институт проблем нефти и газа РАН, г. Москва; \\ 2 - НТЦ «Транскор-К», г. Москва \\ E-mail: *ermn@mail.ru, ${ }^{* *}$ linya82@mail.ru
}

Аннотация. В статье рассмотрены современные методы мониторинга технического состояния трубопроводов, пролегающих в сложных условиях. В рамках методологии рискориентированной диагностики (Risk Based Inspection) проанализирован подход с применением инновационного метода магнитной томографии, предлагающего включение регистрации реальных механических напряжений в систему оценки надежности трубопроводов по критерию перехода в предельное состояние на основе регистрации степени концентрации напряжений или превышения локальных нагрузок.

Ключевые слова: нефтепровод, газопровод, метод магнитной томографии, стресскоррозионные процессы, Виллари-эффект, коррозия, коррозионное растрескивание под напряжением, охрупчивание металла, внутритрубная инспекция, мониторинг состояния трубопровода, напряженно-деформированное состояние, ферромагнитный материал.

Для цитирования: Дмитриевский А.Н., Еремин Н.А., Хуснутдинов Л.А. Мониторинг состояния трубопроводов в сложных условиях // Актуальные проблемы нефти и газа. 2019. Вып. 3(26). https://doi.org/10.29222/ipng.2078-5712.2019-26.art12

\section{Литература}

1. Белов А.А., Иванов Ю.Д., Шестаков А.А., Царева С.Г., Шишков Э.В. Рекомендации по выбору способа мониторинга технического состояния трубопроводов. // Актуальные проблемы гуманитарных и естественных наук. 2015. № 10-1. С. 1-5.

2. CAE-CUBE. http://cae-cube.ru/ (Дата обращения 11.02.2018).

3. Svelto C., Pniov A., Zhirnov A., Nesterov E., Stepanov K., Karassik V., Galzerano G., Laporta $P$. Online monitoring of gas \& oil pipeline by distributed optical fiber sensors // Offshore Mediterranean Conference and Exhibition, 27-29 March 2019: Proceedings. Ravenna, Italy, 2019. Paper OMC-2019-0830. 9 p.

4. Stubelj I.R., Ruschmann H., Wold K., Gomnaes J.O. Pipeline predictive analitics trough on-line remote corrosion monitoring // NACE Conference\&Expo CORROSION 2019, 24-28 March 2019: Proceedings. Nashville, Tennessee, USA, 2019. Paper NACE 2019-12899. $14 \mathrm{p}$.

5. Wright R.F., Egbu J., Buric M., Ziomek-Moroz M., Ohodnicki P.R., Lu P. Electrolessly coated optical fibers for distributed corrosion monitoring // NACE 
Conference\&Expo CORROSION 2019, 24-28 March 2019: Proceedings. Nashville, Tennessee, USA, 2019. Paper NACE 2019-13499. 12 p.

6. Guan S., Ayello F., Sridhar N., Han X., Feng Q., Yang Y. Application of probabilistic model in pipeline direct assessment // NACE Conference\&Expo CORROSION 2019, 24-28 March 2019: Proceedings. Nashville, Tennessee, USA, 2019. Paper NACE 2019-12718. 13 p.

7. РД 102-008-2002. Инструкция по диагностике технического состояния трубопроводов бесконтактным магнитометрическим методом. М.: Изд АО ВНИИСТ, Минэнерго, 2003. 52 с.

8. Jarram P. Developments in remote magnetic monitoring of carbon steel pipelines to locate and measure abnormal stress // NACE Conference\&Expo CORROSION 2019, 24-28 March 2019: Proceedings. Nashville, Tennessee, USA, 2019. Paper NACE 2019-12995. 21 p.

9. Дмитриевский А.Н., Еремин Н.А., Камаева С.С., Черников А.Д. Бесконтактная диагностика нефтегазопроводов: состояние и перспективы развития. // Актуальные проблемы нефти и газа. 2018. Вып. 1(20). https://doi.org/10.29222/ipng.2078-5712.201820.art11

10. Marathe S. Leveraging Drone Based Imaging Technology for Pipeline and RoU Monitoring // SPE Symposium: Asia Pacific Health, Safety, Security, Environment and Social Responsibility, 23-24 April 2019: Proceedings. Kuala Lumpur, Malaysia, 2019. Paper SPE195427-MS. 18 p. https://doi.org/10.2118/195427-MS.

11. Еремин Н.А., Хуснутдинов Л.А. Вопросы мониторинга стресс-коррозионных процессов внутрипромысловых трубопроводов в сложных условиях // Нефтяная провинция. 2018. № 4(16). C. 196-211. https://doi.org/10.25689/NP.2018.4.196-211 